\title{
Lungekreft og samtidig opptredende sykdommer
}

Komorbiditet kan påvirke både utvikling av og overlevelse ved lungekreft.

I Norge ble det i 2010 diagnostisert 2826 lungekrefttilfeller. Ved utgangen av 2010 var femårsoverlevelsen $16 \%$ hos kvinner og $11 \%$ hos menn. Lungekreft diagnostiseres ofte $i$ et sent stadium når helbredende behandling ikke lenger er mulig. Tidlig diagnostikk er dermed viktig for å kunne tilby flere pasienter helbredende behandling. Gjennomsnittlig alder ved diagnosetidspunkt er ca. 70 år, og derfor har mange lungekreftpasienter tilleggssykdommer. Det har vært uavklart om samtidig opptredende sykdom påvirker utvikling av og overlevelse ved lungekreft. Avhandlingens målsetning var å beskrive hvordan andre sykdommer påvirker risiko for lungekreft (hjerte- og karsykdom, osteoporose) og overlevelse ved lungekreft (diabetes mellitus).

Pasienter med lungekreft og diabetes hadde en signifikant lengre overlevelse enn lungekreftpasienter uten diabetes $(10 \mathrm{md}$. vs. 6 md., $p=0,007)$. Muligens kan forskjellen delvis forklares med bruk av metformin. Både kvinner og menn med lav beintetthet hadde en 2,5 ganger forhøyet risiko for å utvikle lungekreft. Muligens skyldes dette andre tilstander knyttet til osteoporose, slik som vitamin D-mangel. Pasienter med hjerte- og karsykdom hadde 1,5-2 ganger høyere risiko for å få lungekreft uavhengig av røykemengde. Kanskje kan funnet forklares med kronisk inflammasjon hos pasienter med hjerte- og karsykdom.

Avhandlingen viser at samtidige sykdommer kan ha betydning for risiko for å utvikle lungekreft og påvirker overlevelse hos pasienter med lungekreft. Resultatene kan få betydning både for fremtidig klinisk forskning og for screening.

\section{Peter Hatlen}

peter.hatlen@ntnu.no

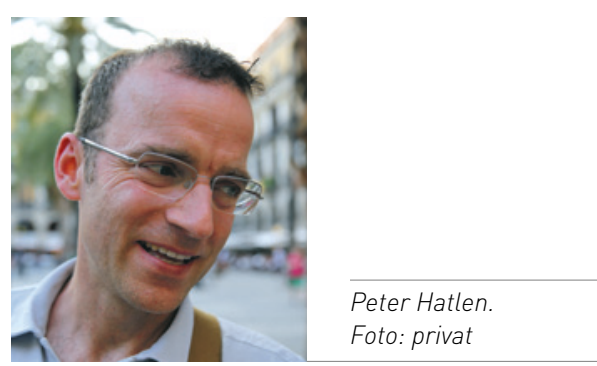

Disputas

Peter Hatlen disputerte for ph.d.-graden ved Norges teknisk-naturvitenskapelige universitet 6.2. 2014. Tittelen på avhandlingen er Lung cancer-influence of comorbidity on incidence and survival. The Nord-Trøndelag Health study.

\section{Ny viten om}

\section{nervecellekommunikasjon}

\section{Forståelsen av kommunikasjonen over synapsespalten som et enveis- signal er i endring. Aspartat synes å være et viktig signalstoff.}

Inntil nylig har den tradisjonelle oppfatningen vært at aktiverende og hemmende signalstoffer er lokalisert i ulike typer terminaler og at signalet går én vei, fra terminalen til dendritten. Signalstoffkandidaten aspartat finnes i både aktiverende og hemmende synapser.

I avhandlingen min viser jeg at aspartat og glutamat tas opp i ulike vesikler. Etter behandling med epilepsimedisinen valproat reduseres nivået av aspartat i terminalene, men ikke av glutamat, noe som åpner for at vesikkelinnholdet av disse reguleres forskjellig. Acetylert aspartat (NAA) er imidlertid ikke lokalisert i synapser. Avhandlingen avdekker at $\mathrm{N}$-acetylaspartat er lokalisert i myelin og myeliniserende celler i tillegg til nerveceller. Studiene vi har gjort på Canavans sykdom, tyder videre på at $\mathrm{N}$-acetylaspartat er viktig for danning av myelinet, som igjen reduserer signalene som går langs aksonet. Kombinasjonen av N-acetylaspartat og glutamat, $\mathrm{N}$-acetylaspartylglutamat (NAAG) ser ut til å virke som et retrograd signalstoff, dvs. at den frigjøres fra dendritten mot terminalen når aktiveringen derfra er for sterk. Glutamat, aspartat, $\mathrm{N}$-acetylaspartat og $\mathrm{N}$-acetylaspartylglutamat er ikke bare biokjemisk nært knyttet, men de ser ut til å være viktige for hver sin del av signaleringen i hjernen.

Funnene bør bidra til å endre tolkingen av MR-spektroskopi, der reduksjon i N-acetylaspartat har vært tolket som nervecelledød. Videre gir resultatene ny forståelse og nye behandlingsmuligheter ved epilepsi, der det er misforhold mellom aktiverende og hemmende signaler mellom nervecellene i hjernen.

Kaja Nordengen

kaja.nordengen@medisin.uio.no

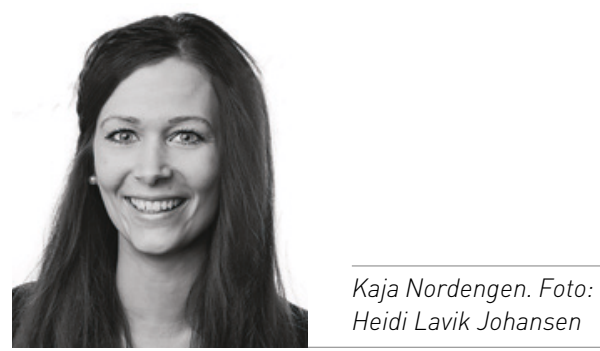

Disputas

Kaja Nordengen disputerte for ph.d.-graden ved Universitet i Oslo 24.4. 2014. Tittelen på avhandlingen er The localisation and function of NAA, NAAG and their derivatives in the brain. 